\title{
Religious Experience without Belief? Toward an Imaginative Account of Religious Engagement
}

\author{
Amber L. Griffioen
}

\author{
Our dreams are more romantic \\ Than the world we see \\ And if the things we dream about \\ Don't happen to be so \\ That's just an unimportant technicality \\ FROM THE SONG 'MAKE BELIEVE' IN SHOWBOAT: THE MUSICAL
}

It is commonly supposed that a certain kind of belief is necessary for religious experience. This claim gets cashed out in various ways in the philosophical and theological literature. For example, on some accounts religious experience is subjectively self-verifying - that is, one cannot have a religious experience without in some sense believing in the existence of the intentional object of the experience. ${ }^{1}$ On other, more nuanced accounts, religious experience always minimally involves a belief about the causal origin of the experience. (That is, it is not possible to have an experience of God if one sincerely judges the experience to be purely naturalistically explicable). ${ }^{2}$ Yet it is not clear that this must be so. In what follows, I will defend the possibility that a subject could have a genuine emotional religious experience without thereby necessarily believing that the purported object of her experience corresponds to reality and/or is the

1 Rudolf Otto might hold a version of this view. For Otto, it seems that although genuine religious experience itself is technically non-conceptual and non-discursive, experiencing mysterium tremendum et fascinans still appears to involve a belief in the existence of the "numinous". See Rudolf Otto, The Idea of the Holy, trans. John W. Harvey (London: Oxford University Press, 1958).

2 See, for example, Wayne Proudfoot, Religious Experience (Berkeley, cA: California University Press, 1985). 
cause of her experience. To do so, I will put forward what I call an imaginative account of religious engagement. Imaginative engagement, I will argue, may evoke emotional religious experiences that may be said to be both genuine and appropriate, despite not necessarily including beliefs of the aforementioned kind. Indeed, I maintain that such religious engagement is compatible not only with non-belief but also with disbelief. (For purposes of brevity, however, I will usually simply refer to the distinction between 'believers' and 'nonbelievers', which is meant to include not only those who remain agnostic or who lack a belief one way or the other but also those who reflectively disbelieve or deny the truth of the relevant propositions.)

\section{Religious Engagement: An Imaginative Account}

We often set up the terms 'imagination' and 'reality' as contrasts. Yet this can be misleading. In many instances, imagination is required for us to represent things we take to really exist or have happened, as when we represent very large or small things (like galaxies or DNA) to ourselves or when we picture spatially or temporally non-present events (as when we imagine what Mardi Gras in New Orleans or the Battle of the Bulge must be/have been like). Engagement with religious concepts, too, requires a significant degree of imaginative activity, even for those who believe those concepts correspond to reality. Engaging with concepts like 'God', 'the Transcendent', 'Ultimate Reality', 'the beatific vision', and so on - and being able to understand and meaningfully utter sentences like 'The Holy Spirit proceeds from the Father and the Son' - seems not only to require imagination but also to take us to the very limits of what we as finite human subjects can represent to ourselves. Likewise, regardless of whether any particular religious story is true or not, to understand the whole of the history of the world as a kind of 'divine narrative' - one featuring, for example, the interaction of natural and supernatural agents, a struggle between good and evil, or an eschatological resolution - requires an imaginative narrative understanding that goes beyond mere claims about certain historical or empirical 'facts'. Moreover, participation in religious ritual, be it in the form of taking the Eucharist, engaging in merit-making, or even simply praying, involves opening oneself up imaginatively to the idea of something which putatively transcends our empirical understanding, even if it is also limited by our own conceptual constraints. In all these ways, the imagination is no stranger to the sphere of religion. If anything, it appears an essential part of it. ${ }^{3}$

3 Garrett Green makes a similar claim in Imagining God:Theology and the Religious Imagination (San Francisco, CA: Harper \& Row, 1989). 
Yet such imaginative activity is not restricted to believing subjects. Nonbelievers, too, can employ their imaginations in the service of religious participation and engagement, even if they do not believe the propositions involved in such engagement are literally true or that the content of the concepts they employ corresponds to something actual. Indeed, it seems perfectly possible that a subject may have (good) practical reasons for pursuing a life of religious participation, despite finding herself unable (or unwilling) to be completely confident of the truth of that particular tradition's content. ${ }^{4}$ For example, an epistemically cautious subject may suspend judgment regarding certain articles of faith and yet consistently adopt a hopeful or optimistic attitude toward them. One may even believe these propositions are, strictly speaking, false, yet imaginatively engage with the relevant concepts in ways similar to those in which we engage with fictional entities and settings. In fact, I think this is something we commonly see when we look at what many religious adherents 'on the ground' actually do, as opposed to focusing on more abstract philosophical and theological treatments of the religious life.

Of course, the religious believer employs her imagination to represent something she thinks actually exists. She thinks that when she says, 'God is omniscient', she says something that is true. What about religiously-engaged non-believers like those in the examples above? On one understanding (e.g., that put forward by certain versions of theological fictionalism), ${ }^{5}$ the nonbeliever thinks that the statement 'God is omniscient' is literally false, but she 'pretends' or 'makes believe' that the statement is true. She acts 'as if' there were such a being as God who knows everything there is to know. Now surely there is something right about this picture of the religious non-believer, in the sense that she does willfully enter into a certain imaginative context, one which employs concepts and makes claims that she thinks do not necessarily correspond to reality. Yet there is no need for us to say that just because the non-believer takes these statements not to refer to really existing entities and states of affairs she must take them to be false tout court. Just as there is a sense in which the claim 'Jane Eyre is a governess' is true (it is wrong, for example, to say that Jane Eyre is a professional baseball player), there is a very legitimate sense in which, when the religiously committed non-believer says 'God is omniscient', she likewise says something that is true - at least from within the context of certain monotheistic traditions. Similarly, the statement 'God

4 There are several candidates for such reasons, ranging from moral to aesthetic to purely prudential, and (as I discuss below) many corresponding attitudes that one might adopt (such as hope, optimism, acceptance, etc.).

5 See, for example, Robin Le Poidevin, Arguing for Atheism (London: Routledge, 1996) and Andrew Eshleman, “Can an Atheist Believe in God?", Religious Studies 4 (2005), 183-199. 
is triune' is false from within Jewish or Muslim contexts, just as the statement 'Captain James T. Kirk was born in Minnesota' is false in the Star Trek Universe. ${ }^{6}$ So there is no need here to say that religious believers and non-believers within a certain tradition are necessarily talking past each other when they engage in religious discourse. In fact, if we accept that many or most religious concepts require a certain degree of imaginative engagement on the part of all religious subjects, we might be in a better position to examine how dialogue within a certain religious context can get off the ground in the first place. ${ }^{7}$

So just what is the difference between the religious believer and non-believer in such imaginative contexts? From within the religious context, the gap might not be as great as we may have first thought. Still, there will be a relevant distinction between the two. One possible way of understanding this difference is to say whereas believers believe (and thereby accept) that $p$, non-believers merely accept that $p$. What is the difference? According to William Alston, whereas belief is a non-voluntary dispositional state in which we simply 'find' ourselves, acceptance involves a voluntary mental act. Alston claims that both believers that $p$ and 'mere acceptors' that $p$ will be disposed to behave in similar ways as far as action regarding $p$ is concerned (e.g., affirming $p$ in relevant action-contexts, using $p$ as a premise in their theoretical and practical reasoning, and so on), with one minor difference: for the non-believer, "[t]he complex dispositional state engendered by accepting $p$ will definitely not include a tendency to feel that $p$ if the question of whether $p$ arises", whereas for believers this tendency is present. ${ }^{8}$ But, importantly, the question of 'whether $p$ ', as a question that calls for ontological or metaphysical speculation (or one about whether some event actually happened), is not necessarily or even commonly

6 According to the Star Trek canon, Captain Kirk was (or will be) born in Iowa.

7 The notion of 'true or false within a religious context' will, of course, raise interesting questions regarding religious disagreement and interreligious dialogue; see, for example, some of the problems raised in Victoria Harrison, "Philosophy of Religion, Fictionalism, and Religious Diversity", International Journal for the Philosophy of Religion 68 (2010), 43-58. I do not have space to go into these issues here, but I think a discussion of what inter- (and intra-) religious disagreement and dialogue might look like on a fictionalist account - or on any antirealist picture, for that matter - is warranted. This may also provide us with a motivation to move away from strictly fictionalist and toward what I am calling 'imaginative' accounts of religious discourse, where the issue centers not specifically around whether or which God exists but rather around a discussion that focuses on the evaluation of which imaginative concepts are most useful, helpful or morally salient.

8 William Alston, "Belief, Acceptance, and Religious Faith", in Faith, Freedom, and Rationality, ed. Jeff Jordan and Daniel Howard-Snyder (Lanham, MD: Rowman \& Littlefield, 1996), 10-27 (10), additional emphasis mine. 
a question taken up from inside the religious tradition. And where it is taken up from within the tradition, what does it matter if some individuals lack a tendency to 'feel' that $p$ in these contexts? It does not mean they never feel that $p$ - rather, it is only from the standpoint of ontological speculation that they differ in feeling from their believing counterparts. But this is simply to affirm that there is sometimes a phenomenological difference between believers and non-believers when it comes to ontology, which is, of course, exactly what we would expect. So acceptors need not believe that $p$, though presumably they must approve of $p$ in some sense. As Daniel Howard-Snyder notes, belief that $p$ is not required for what he calls "propositional faith", but rather only a positive cognitive and affective/conative stance toward $p .{ }^{9}$ One such stance, as James Muyskens has suggested, might be that of hope. ${ }^{10}$ Thus, as hinted at above, perhaps the non-believer need merely hope that $p$ be true, even if she does not believe it. ${ }^{11}$ In any case, it seems clear that one can practically commit oneself to religious propositions without having to believe them to actually 'match up' with reality. ${ }^{12}$

Likewise, one can sincerely accept and adhere to religious norms without belief, which may involve one's being further committed to engaging in certain religious practices and rituals. For example, we can imagine someone committing herself to wearing the Hijab without believing that it is actually divinely ordained - perhaps because it encourages religious devotion, modesty, and humility. Or we can imagine a Taoist burning joss paper during Ghost Month, even though he is unsure whether his deceased ancestors are actually benefitted by such a practice. In neither case, need the practitioner be convinced of

9 Daniel Howard-Snyder, "Propositional Faith: What It Is and What It Is Not", American Philosophical Quarterly 50 (2013), 357-372. Howard-Snyder puts forward a few other criteria for propositional faith as well, with which I take some issue, but that is not relevant to my discussion here.

10 James Muyskens, The Sufficiency of Hope: Conceptual Foundations of Religion(Philadelphia: Temple University Press, 1979).

11 Of course, hoping that $p$ requires believing that $p$ is at least possible, and I would argue that even this need not be the case on an imaginative account of religious engagement. However, as Greg Landini has pointed out in personal conversation, even if a person believes that $p$ is metaphysically impossible, she might still hope that she is wrong about this.

12 Moreover, even among believers there are many different ways in which one can understand or interpret religious propositions - literally, analogically, metaphorically, narratively, mythologically, and so on. Thus, once we move beyond straightforward literal interpretation of religious propositions, the gap between the believer and the nonbeliever appears very narrow indeed. 
the truth of the relevant propositions, though he or she may certainly accept or hope or act as if they are. Further, as I have intimated, I think sincere religious engagement is compatible even with disbelief. This is because what is required for sincerity in the case of religious engagement has more to do with the strength of one's practical commitment to the relevant aspect of the religious tradition than with that of one's epistemic commitment to it. To be sure, the latter often does strongly inform the former - and sincere religious engagement may, as a matter of contingent psychological fact, generally be less effortful for the believer than the non-believer. But even this does not follow with necessity. For one may have a strong belief that $p$ and yet be hostile or uncommitted to acting on it. ${ }^{13}$

So perhaps the relevant distinction between the religiously committed believer and non-believer is that, although both may be equally practically committed to certain religious propositions and concepts, when the former steps 'outside' of the strictly religious context or examines it from a critical standpoint, she affirms that, for example, God is an actually existing feature of the universe, whereas the latter denies this. Another way to put this is that when the believer engages in ontological or metaphysical speculation - when she thinks about what there really is and how it is constituted - she affirms that the statements she makes within the religious contexts really refer. The nonbeliever, on the other hand, denies this. But although this may be one way to engage with religion (critically, from the outside), it is certainly not what religion is centrally about. Put a bit differently, although metaphysical speculation or natural theology may be an important - perhaps even essential - feature of engagement within some religious and mystical traditions, it does not seem to me that the essence of religion per se is to be found in existence-assertions regarding correspondence with reality. ${ }^{14}$

Still, one might claim that for the 'truly' religious individual, there is no 'stepping outside' the religious context. Religion, one might argue, colors all aspects of experience, such that anyone who can compartmentalize and view her religious tradition 'from the outside' cannot be said to be sincerely religious engaged. It is easy (and appropriate), the objector might claim, to step out of the fictional Jane Eyre or Star Trek universe once in a while, but it is not

\footnotetext{
13 As James 2:19 states, "The demons also believe and shudder". But surely they do not count among the religiously faithful.

14 This is not to say that certain religious propositions do not perform an explanatory function. It is, however, to deny that a concern for explanation is at the heart of the religious life, even if some "proto-religions" may have their origin in efficient-causal explanatory attributions.
} 
so simple (nor ought it be) to step outside of a particular religious context. Yet this is to confuse the matter. Although it is true that, ideally, religion is more than a set of practices - it is a form of life, a way of being - this does not mean one cannot step outside it or consider it from alternative perspectives. If it were, then interreligious dialogue and dialogue between the non-religious and the religious would be doomed from the get-go. (I know there are those who support this view, but I find it overly pessimistic.) Second, even though the religious believer and non-believer affirm inconsistent things about the makeup of the universe in extra- or supra-religious contexts, this does not mean that their experience within that context is relevantly different, or that their lives as a whole cannot be equally enriched by engagement with a religious form of life.

However, in order to make this latter assertion, I will have to defend the claim that religiously engaged non-believers are capable of having genuine religious experiences of the kind relevant to a meaningful religious life. For although the level of religious commitment may be the same between certain believers and non-believers, if the latter are - by virtue of their non-belief incapable of genuine religious experience, this may count as a strike against the kind of imaginative model I am proposing here.

\section{Applying the Imaginative Account: The Case of Religious Experience}

First, we must say a bit more about what we mean by the term 'religious experience'. On the view I am advocating here, in order to count as a specifically religious experience, the subject has to view her experience in light of some particular religious tradition or conceptual schema, and that particular tradition or schema must enter in some way into the content of her experience. Thus, a mere feeling of contingency might not count as a straightforwardly religious experience, but the "feeling of absolute dependence" understood in Friedrich Schleiermacher's sense or the "creaturely feeling" we find in Rudolf Otto might, assuming they are interpreted from within a religious framework. ${ }^{15}$ Otherwise they might count as mystical or spiritual (but not specifically religious) experiences. In other words, although I am not taking a position on whether there is some perennial element independent of interpretation and common to all experiences of a 'spiritual' nature, I do think that to count as

15 See Rudolf Otto, The Idea of the Holy, and Friedrich Schleiermacher, The Christian Faith, trans. Hugh R. Mackintosh and James S. Stewart (London: T\&T Clark, 1999). 
religious, an experience must be viewed through the conceptual lens of some particular religious tradition or traditions. ${ }^{16}$ However, little of what I am going to say here hinges on this (admittedly vague) account being correct.

Further, when I say 'genuine' religious experience, I do not mean that it must be understood factively - as only genuine if it was, in fact, caused by what it is about. (Though 'what it is about' is sometimes more difficult to get at than we might think. I return to this below.) Finally, I should note that I am focusing on an important subset of religious experiences, namely those experiences that are fundamentally affective or emotional in nature. The term 'religious experience' may encompass a wider set of experiences than the merely affective (such as intellectual apprehensions, visions and auditions, sensed presences, out of body experiences, and so on), but these are not my concern here. What concerns me is whether the religiously engaged non-believer can genuinely experience religious emotions, and how (if at all) they might differ from the religious emotions of believers.

Engaging with religious concepts and propositions requires some cognitive accomplishment on the part of the religious subject, yet I have claimed that this cognitive role a) may (and perhaps must) involve the religious imagination and b) need not involve full doxastic commitment, or belief. I have also hinted at the idea that the non-believer - who doubts that such concepts and propositions refer to actually existing entities - might engage with them in a way similar to the way we engage with concepts and propositions in fictional settings. ${ }^{17}$ It will be helpful here to examine this idea a bit more closely. When we engage with fiction sincerely - that is, when we immerse ourselves in a piece of fiction or otherwise 'take it seriously' - it is not as though we forget or somehow fail to realize that we are dealing with situations we take to be non-actual. Yet we do tend to distract ourselves from reflecting too heavily on this fact. Indeed, fictional engagement often requires a kind of a temporary 'letting go of' or psychologically 'distancing oneself from' certain aspects of (perceived) reality that might conflict with our being able to take the fiction seriously. ${ }^{18}$ And this is something we do successfully on a regular basis without

16 By 'religious tradition' I have in mind something social, institutional, and historical. But I am aware that there are competing scholarly understandings of religion. Still, I think most of these theoretical accounts are compatible with the idea of religion as a kind of 'lens' or 'orientation' through which an experience may be interpreted.

17 This is not the only way one may imaginatively engage as a non-believer, but it is the one I will focus on in the remainder of this essay.

18 For example, in order to enjoy the television show "24", one must perhaps not reflect too heavily on the fact that mere mortals do not generally exemplify the physical resilience of a Jack Bauer, or be willing to accept that one can make it across Los Angeles in ten minutes during rush hour. 
much cognitive difficulty or dissonance: we bracket certain metaphysical and ontological presuppositions in order to be able to properly enjoy the fiction with which we are engaging.

But why do we care about being able to enjoy fiction? What value might it have for our lives? There are various answers one might provide here: that engaging with fiction allows us to expand our imaginative horizons, making us more flexible in our everyday lives; that it increases our sense of empathy by allowing us to engage with characters we will likely never meet; that it allows us to travel imaginatively to places and times to which we have not been (nor perhaps has anyone else) ${ }^{19}$ Or perhaps engaging with fiction, like playing sports or music (or doing philosophy!), is enjoyable for its own sake. In any case, we would be hard-pressed to find someone who thinks that engaging with drama, literature, film, and the like does not contribute in any way to human flourishing. In fact, I think most people would agree that their lives are in some way 'enriched' by their engagement with fiction. ${ }^{20}$

Still, there are some persons for whom suspending disbelief, bracketing metaphysical considerations, or otherwise mentally compartmentalizing may be more difficult. And for such people, enjoying certain fictions (or being able to take them seriously) will not come as easily as for others. Then there are those persons who take fiction more seriously than their more skeptical counterparts. Role-playing games, cosplay, fan fiction, historical re-enactments, and other similar activities represent ways in which fiction and pretense may take on a more concrete role in one's everyday life. But such enthusiasts need not be characterized as delusional or pathological - they merely engage with fiction in a more concrete fashion than those of us who simply leave the book on the nightstand. Of course, most of us fall somewhere in the middle of this spectrum. ${ }^{21}$

19 Keith Oatley, for example, argues that engaging with fiction can have beneficial results in the "exploration of the minds of others, investigation of relationships, dynamics of interactions in groups, and grappling with the problems of selfhood". Keith Oatley, Such Stuff as Dreams: The Psychology of Fiction (Oxford: Wiley, 2011), 167.

20 It is important here to note that certain types of fictional engagement may, in fact, be harmful, depending on the nature and content of the fiction with which one engages (see Keith Oatley, Such Stuff as Dreams, 167). But the same may be said for religious engagement. Still, nothing about what I say here regarding the possibility of religious experience by engaging imaginatively with religious concepts hinges on this. One could also have religious experiences within a religion which is morally bad.

21 Similarly, there are often particular fictional contexts with which we find ourselves more able and/or willing to sincerely engage than others. I might be a huge Battlestar Galactica fan, where you find it difficult to take science fiction seriously. Perhaps you prefer historical fiction or romance novels. This may have important parallels in the religious 
Yet regardless of where we find ourselves on this continuum, assuming we are capable of 'letting go' enough to enjoy fiction in some capacity, we will also notice that we appear to be capable of being emotionally affected by it. We cry when a beloved character dies; our flesh crawls when we watch a creepy horror film; we feel torn and upset when a character faces a moral dilemma; and we rejoice when the hero overcomes a difficult obstacle to triumph over evil. Still, we might wonder whether such phenomena represent genuine emotions and, if so, whether such emotions might not be irrational, misplaced, or otherwise inappropriate, given that they have as (at least part of) their content non-existent entities and states of affairs. The answer that we give to this question will affect the way we view the experiences of committed non-believers in imaginative religious contexts.

In a seminal piece on this question, Kendall Walton has argued that the feelings we experience when we encounter fiction are not really emotions at all - they are better understood as quasi-emotions. ${ }^{22}$ Although they bear certain similarities to 'genuine' emotions, they differ in that they do not require the existence of their objects and that they do not appear intrinsically tied to motivation and action. Colin Radford, on the other hand, has argued that the emotions themselves are genuine, but they are misdirected or irrational, since their objects do not exist. ${ }^{23}$ However, Tamar Szabó Gendler and Karson Kovakovich have (I think persuasively) argued against both of these positions, and with good reason. ${ }^{24}$ First, they note, it simply begs the question to assume that genuine emotions are only those whose objects exist or that all emotions with non-existent objects are, by virtue of this fact, irrational. Both claims threaten to reduce the debate to a mere lexical dispute. ${ }^{25}$ Further, they argue that it is false that fictional emotions are not linked to action. They cite a series of studies by Antonio Damasio which conclude that imagining certain (non-actual) practical consequences of hypothetical behavior triggers emotional mechanisms that serve as "somatic markers" which then assist in guiding future behavior. And the "simulated emotions" in play here are not

case, since aesthetic preferences can and do play a role in one's ability and willingness to sincerely participate in certain religious traditions or practices.

22 See Kendall Walton, Mimesis as Make-Believe (Cambridge, MA: Harvard University Press, 1990), 195-202.

23 See Colin Radford, "How Can We Be Moved by the Fate of Anna Karenina?", Proceedings of the Aristotelian Society, supp. vol. 49 (1975), 67-8o.

24 See Tamar Szabó Gendler and Karson Kovakovich, "Genuine Rational Fictional Emotions", in Contemporary Debates in Aesthetics and the Philosophy of Art, ed. Matthew Kieran (Oxford: Blackwell, 2005), 241-256.

25 See ibid., 249. 
significantly different from the emotions we encounter when engaging with fiction. Thus, emotions that have as their objects entities or states of affairs the subject herself takes not to exist may not only motivate behavior; they might be crucial for the successful exercise of practical reasoning in the first place. ${ }^{26}$

Further, regarding Radford's claim, it seems wrong to say that every 'fictional emotion' is irrational by virtue of being targeted at and/or triggered by a fictional object. There certainly seem to be inappropriate emotional responses with regard to fiction. (We would think it inappropriate for someone to take joy in the moral dilemma in which the title character of Sophie's Choice finds herself.) But the fact that there appear to be inappropriate emotional responses to fiction implies that there are also appropriate ones. Indeed, there would appear to be no possibility of a substantive debate about the appropriate way to feel within certain fictional contexts if all such emotions are per se irrational or inappropriate.

What is the upshot of this discussion? If Gendler and Kovakovich are right, and we can "respond with genuine, rational emotions to targets that we believe to be fictional", ${ }^{27}$ then it does not seem all that far-fetched to extend this conclusion to religious emotions in the case of the non-believer. Now, it might be the case that the believer experiences such emotions more vividly or intensely than the non-believer (just as the death of a close friend affects me more strongly than the death of a beloved fictional character), but this is an empirical matter - one which I am not sure would be borne out in every case of religious emotion. Even if it were, however, it would only demonstrate that there is a quantitative, not a qualitative, difference in emotion between the religious believer and non-believer. Further, as with our engagement with fiction, engagement with religion might open us up to new ways of seeing the world and ourselves: it might allow us to develop a "sense and taste for the infinite" 28 - to see the universe as disclosing transcendence, as a matter of "Ultimate Concern"29 - to understand our own contingency and our special place in the world. Viewing an occupation as a vocation, a calling, instead of a mere job may imbue our lives with a sense of meaning, even if we take there to be no one who has actually called us. Viewing our moral duty as divinely

26 See Antonio Damasio, The Feeling of What Happens: Body and Emotion in the Making of Consciousness (New York: Harcourt, 1999), cited in Tamar Szabó Gendler and Karson Kovakovich, "Emotions", 247-248.

27 Tamar Szabó Gendler and Karson Kovakovich, "Emotions”, 253.

28 See Friedrich Schleiermacher, On Religion: Speeches to Its Cultured Despisers, trans. Richard Crouter (Cambridge: Cambridge University Press, 1988).

29 See Paul Tillich, Dynamics of Faith (New York: Harper Collins, 2001). 
ordained may help us develop characters that are more virtuous and more loving, even if we think there is ultimately no 'divine commander'. ${ }^{30}$ Indeed, emotions in simulative contexts might not only be important for practical reasoning - they may be necessary for us to view ourselves as agents-in-theworld in the first place, and religious emotions have their place in this schema too. In any case, I think a case can plausibly be made that the imaginativelyengaged religious life can and does (at least in some instances) contribute positively to human flourishing.

\section{What Kind of Religious Emotion?}

However, one might object here that I am too hasty and too vague with my characterization of religious emotions. One might argue that while we may feel 'basic' emotions like joy, sadness, anger, amusement, fear and so on in response to fictional characters and states of affairs, the emotional states characteristic of religious experience are not those we typically experience in fictional contexts. So what should we say here? Are the paradigmatic religious emotions of a kind that can (non-pathologically) be experienced by a non-believer? To begin, I think that at least some paradigmatic religious emotions are not particularly problematic for the non-believer. Awe, wonder, fear, mystery, Otto's mysterium tremendum et fascinans, even Schleiermacher's "feeling of absolute dependence"31 - I think all of these can be fairly straightforwardly experienced by the imaginatively-engaged non-believer. Indeed, imaginative engagement with particular religious concepts in certain contexts might be the exact kind of thing that makes such experiences possible for any subject, believer or not.

Interestingly, in none of the cases just mentioned is the actual target of the emotion God. I feel awe in response to a magnificent Alpine landscape; I wonder at the expanse of the night sky; I tremble at the uncanny stillness of an empty church; I thrill at the swelling of a choir's voices; I feel 'creaturely' and dependent when I imagine myself as a tiny speck in a greater universe; and so on. In these kinds of emotional experiences, the direct target of my experience (and, in many cases, its proximate cause) is something worldly and immanent, something existent. In the latter case, it may even be my own self

3o Further, we can imagine a philosophically-minded theist who finds theological intellectualism more theoretically persuasive - yet who is (rightly) concerned about the sources of normativity - adopting a divine voluntarist model as a "useful fiction" to motivate action or serve as a practical guide to everyday life. 
that is both the subject and the object of the emotion. Even for the believer, there is no direct perception of God here - indeed in many religious traditions, it would be heresy to maintain that such a thing is even possible. Where God is 'perceived' by the believer in religious experience, God becomes present only indirectly, via the actual target of the experience. ${ }^{32}$ In any case, what makes these experiences religious has more to do with their being interpreted from within the framework of a religious tradition in which one is willingly and sincerely engaged, their being articulated with the use of religious terms and propositions, and their being colored by these concepts in a way that nonreligiously interpreted experiences are not.

This is a kind of experience that both the believer and the non-believer can 'make' (to speak, as the Germans do, of Erfahrung machen). And while such experiences may be correlated with a belief in the existence of the divine, they need not be. The inferences that one draws from a religious experience may be vast and wide-ranging. Thus, pace Wayne Proudfoot, I do not think that the noetic quality of a religious experience - its informative, cognitive aspect - must involve an explanatory judgment about the causal origin of the experience. Proudfoot maintains that were I to provide a wholly naturalistic explanation of my experience, I could not view it as religious. ${ }^{33}$ Yet anyone who has taken a hallucinogenic substance knows that one can be genuinely afraid of something they 'know' is a drug-induced hallucination. Instead, I would argue, the noetic quality of emotional religious experience has more to do with a kind of self-knowledge - one perhaps combined, in some cases, with a deeper sense of one's relation to others - than with beliefs about the existence of a divine reality.

Still, one might argue, there are further paradigmatic religious attitudes interactive, second-personal attitudes like those of gratitude, trust, and love that may be closed off to the non-believer. Of course, unlike experiences of awe and wonder, none of these latter attitudes is, strictly speaking, a discrete

32 This is, of course, in contrast to such accounts of religious or mystical experience that purport to be 'direct perceptions' of God. See, for example, William Alston's Perceiving God: The Epistemology of Religious Experience (Ithaca, NY: Cornell University Press, 1991). While I leave it open that such experiences may be possible, I do not think they are common within everyday religious practice.

See Wayne Proudfoot's discussion of William James in his chapters on "Mysticism" and "Explanation" in Religious Experience. Proudfoot's analysis of the explanatory feature of religious experience is much more nuanced and subtle than I can reproduce (or refute) here. However, suffice it to say that I part ways with him (and, apparently, with James and others) in claiming that an explanatory judgment is not necessary for religious experience. 
emotional state. They involve larger complexes of cognitive, affective, and volitional states and activities that extend over time. I may feel thankful toward someone, but ultimately gratitude is something I show. I may 'feel trusting' toward someone, but trusting (and especially entrusting) is something I do. Something similar may be said for love. So engaging here goes beyond merely responding emotionally to a stimulus. It also involves something active, temporally extended, and volitional.

But can the religious non-believer feel and do such things? In principle, I do not see why not. To be sure, such attitudes are not typical responses to fiction. It sounds odd to talk about 'trusting' Harry Potter or being 'grateful' to Daenerys Targaryen. And we would think it borderline pathological if someone were to say that she, like Jane Eyre, were 'in love' with Mr. Rochester. Yet simply because we do not generally display interactive attitudes toward fictional characters does not mean we cannot display such attitudes toward nonexistent entities, at least within contexts in which such attitudes are appropriate. First, as with the non-interactive attitudes discussed above, displaying these latter attitudes will also require a stretch of the imagination on the part of the believer. If 'trust', 'gratitude', and 'love' have a univocal (or even analogous) meaning in religious and non-religious contexts, then even the religious believer must conceive of God as a creative, providential, personal being - an anthropomorphization that might require bracketing other things she takes to be true of God (like God's eternality or immutability). ${ }^{34}$ Second, although we do not generally experience such attitudes when we engage with literary or dramatic fiction, it does not mean we are incapable of taking up an imaginative second-person stance. Children often address imaginary persons in play, and even many adults engage in imaginary dialogues (including self-dialogues, in which we take the self as an Other). So it is not really a stretch to think that such imaginative second-person stances are psychologically possible.

Thus perhaps taking on a certain kind of imaginative, second-personal stance may make room for the possibility of a non-believer's adopting the above kinds of attitudes. When we undertake an imagining of the world as created by a benevolent being, we may be able to view our lives as though they were gifts from God, allowing us to respond with a form of gratitude. The same type of imaginative stance may allow us to take on a kind of 'willing passivity', a trusting commitment to accepting what may befall one. Love is not far

34 This is one way of expressing the tensions between apophaticism and cataphaticism or between God's immanence and God's transcendence in certain monotheistic contexts. 
behind here. ${ }^{35}$ If one can cash out these attitudes in this way, then, it seems that religious engagement may help foster such feelings in believers and nonbelievers alike and that the imaginative employment of religious concepts may help to flesh them out or to give them more substance. ${ }^{36}$

\section{Conclusion: Religious Experience without Belief}

In summary, I think there is a way of making sense of emotional religious experience that does not require belief in the existence or truth of the relevant religious concepts or propositions involved in that experience. There is certainly more to be said here, and a full-fledged account of the religious imagination still needs to be provided. ${ }^{37}$ But I hope to have shown that what is central to religious engagement is not necessarily belief, but rather a kind of volitional, imaginative commitment. The experiences that result from such commitment will involve a certain level of imaginative 'interpretation' (or Deutung) - a way of seeing things through a religious 'lens', as it were - but this need not threaten their (in-)genuineness. Furthermore, if I am right that certain forms of religious engagement may contribute positively to human flourishing, it would seem we should start rethinking the way we approach religious faith as well. ${ }^{38}$ Indeed, perhaps religious faith is less about what we believe and more about what we do with what we imagine. And if those things we imagine "don't happen to be so", perhaps "that's just an unimportant technicality". ${ }^{9}$

35 The idea of taking on an imaginative second-personal stance will be especially important in fleshing out an account of what might be going on in prayer as well.

$3^{6} \quad$ For a fascinating example of exercises in pretense and play intended to cultivate a sense for second-personal interaction with God, see: Tanya M. Luhrmann, When God Talks Back (New York: Vintage Books, 2012).

37 For a few helpful sources on the religious imagination and belief, see: Garrett Green, Imagining God; Douglas Hedley, Living Forms of the Imagination (London: T\&T Clark, 2008); and, more recently, Graham Ward, Unbelievable: Why We Believe and Why We Don't (London: I. B. Tauris, 2014).

$3^{8}$ This paper serves as a precursor to the account of religious faith I am currently developing. Unfortunately, I will have to save the intricacies of this view for another occasion.

39 I would like to thank Ulrich Schmiedel, Tobias Tan, and Thomas Hardtke for the organization of the conference at which an earlier version of this paper was presented. I would also like to thank Jörg Lauster, Graham Ward, Scott O'Leary, Ian James Kidd, David Cooper, Clare Carlisle, Dina Emundts, Jochen Briesen, Ursula Renz, Evan Fales, Greg Landini, Daniel Schumacher, Arie Griffioen, and all the others who have given me helpful feedback on some of the central ideas of this paper. 


\section{Literature}

Alston, William, "Belief, Acceptance, and Religious Faith", in Faith, Freedom, and Rationality, ed. Jeff Jordan and Daniel Howard-Snyder (Lanham, MD: Rowman \& Littlefield, 1996), 10-27.

Alston, William, Perceiving God: The Epistemology of Religious Experience (Ithaca, NY: Cornell University Press, 1991).

Damasio, Antonio, The Feeling of What Happens: Body and Emotion in the Making of Consciousness (New York: Harcourt, 1999).

Eshleman, Andrew, “Can an Atheist Believe in God?", Religious Studies 4 (2005), 183-199. Green, Garrett, Imagining God: Theology and the Religious Imagination (San Francisco, CA: Harper \& Row, 1989).

Harrison, Victoria, "Philosophy of Religion, Fictionalism, and Religious Diversity", International Journal for the Philosophy of Religion 68 (2010), 43-58.

Hedley, Douglas, Living Forms of the Imagination (London: T\&T Clark, 2008).

Howard-Snyder, Daniel, "Propositional Faith: What It Is and What It Is Not", American Philosophical Quarterly 50 (2013), 357-372.

Le Poidevin, Robin, Arguing for Atheism (London: Routledge, 1996).

Luhrmann, Tanya M., When God Talks Back (New York: Vintage Books, 2012).

Muyskens, James, The Sufficiency of Hope: Conceptual Foundations of Religion (Philadelphia: Temple University Press, 1979).

Oatley, Keith, Such Stuff as Dreams: The Psychology of Fiction (Oxford: Wiley, 2011).

Otto, Rudolf, The Idea of the Holy, trans. John W. Harvey (London: Oxford University Press, 1958).

Proudfoot, Wayne, Religious Experience (Berkeley, CA: California University Press, 1985).

Radford, Colin, "How Can We Be Moved by the Fate of Anna Karenina?", Proceedings of the Aristotelian Society, supp. vol. 49 (1975), 67-80.

Schleiermacher, Friedrich, On Religion: Speeches to Its Cultured Despisers, trans. Richard Crouter (Cambridge: Cambridge University Press, 1988).

Schleiermacher, Friedrich, The Christian Faith, trans. Hugh R. Mackintosh and James S. Stewart (London: T\&T Clark, 1999).

Szabó Gendler, Tamar, and Karson Kovakovich, "Genuine Rational Fictional Emotions", in Contemporary Debates in Aesthetics and the Philosophy of Art, ed. Matthew Kieran (Oxford: Blackwell, 2005), 241-256.

Tillich, Paul, Dynamics of Faith (New York: Harper Collins, 2001).

Walton, Kendall, Mimesis as Make-Believe (Cambridge, MA: Harvard University Press, 1990).

Ward, Graham, Unbelievable: Why We Believe and Why We Don't (London: I. B. Tauris, 2014). 